\title{
Cycles of Protest: How Urban Cyclists Act Like Insurgents
}

\author{
Lionel Beehner ${ }^{1}$
}

Among the fastest growing movements in U.S. cities are urban cyclists. Vocal in their push for greater rights and respect from drivers, pedestrians, and city officials - as evidenced by Critical Mass rides, the rise in the number of advocacy groups, and the zero-sum discourse employed through their email missives - their emergence as a major social force has received little scrutiny from social movement or urban policy theorists. This paper argues that cyclists are not unlike insurgent movements abroad, with diffuse social networks, a disciplined core membership, and a radical fringe that can engender a counter-movement to roll back the group's gains. The advances made by cycling advocates have been met with a mix of acceptance and opposition - a disparate coalition of well-connected businesspeople and politicians, drivers and pedestrians - that has coalesced to roll back cyclists' rights. Employing qualitative data that includes three months of interviews, as well as a trove of emails to New York's Department of Transportation obtained through a Freedom of Information Act (FOIA) request, this paper takes a social movement theorist's lens to urban cyclists. The case study is a bike lane installed in Park Slope, Brooklyn, in 2010 that generated international headlines after local residents sued the city. The paper finds that the residents were motivated by NIMBY concerns but were also responding to a radical fringe of the cyclist movement, a finding consistent with how locals respond to insurgent movements abroad. [Article copies available for a fee from The Transformative Studies Institute. E-mail address:_journal@transformativestudies.org Website: http://www.transformativestudies.org (02013 by The Transformative Studies Institute. All rights reserved.]

KEYWORDS: Social Movements, Cyclists, Insurgency, Brooklyn, CounterRevolution, Urban Policy.

\footnotetext{
${ }^{1}$ Lionel Beehner is a fellow with the Truman National Security Project, a member of the Atlantic Council's Young Atlanticist Working Group, and term member and former senior writer at the Council on Foreign Relations. He is currently a Ph.D. student at Yale University, where he focuses on social movements, violent non-state actors, and the use of force. He is a member of USA Today's Board of Contributors. He holds a master's degree from Columbia University's School of International and Public Affairs. Address correspondence to: Lionel Beehner Yale University, 43 Chestnut Street \#211, New Haven, Connecticut 06511; e-mail: lionel.beehner@gmail.com.
} 